\title{
Design of energy storage system using solar \& wind power plants for processing \& acquisition data load at BBTA3-BPPT, PUSPIPTEK
}

\author{
Asep Dadan Hermawan, ST. ${ }^{*}$ Dr. Agus Purwadi \\ School of Electrical Engineering and Informatics, Institut Teknologi Bandung \\ Street of Ganesha No.10, Lb. Siliwangi, Coblong, Bandung City, West Java 40132
}

\begin{abstract}
BBTA3-BPPT is a Government Agency that is responsible for carrying out aerodynamic, aeroelastics and aeroacoustics technology activities in Indonesia. The facility that BBTA3 has is ILST (Indonesian Low Speed Tunnel), the devices used in the testing activities are Data Acquisition and Data Processing devices supplied by a state owned electric utility company (PT. PLN) and equipped with UPS. In their operational activities, a power source interruption is sometimes experienced due to the available UPS back up time is between $5-10$ minute; this situation affects the retrieval, processing and data storage system. To overcome this problem, a 4-hours energy storage system can be designed using two sources of energy, namely solar and wind, where the electrical energy generated from both sources will be supplied directly to the UPS battery system. In addition, design estimates and investment costs will be discussed to implement the energy storage system using PV \& Wind Energy network system at ILST - BBTA3, BPPT, Indonesia. It is expected that this study can provide benefits to BBTA3 as a consideration in developing the use of hybrid power system in improving the quality of service.
\end{abstract}

Keywords: Renewable energy, energy storage system, on grid, hybrid power system, ILST.

\section{Introduction}

BPPT unit BBTA3 has the role of clearance test for technology as an authority or supporter in stating that a technology is suitable or not to be applied in Indonesia.

One of the facilities owned by BPPT unit BBTA3 is ILST (Indonesia Low Speed Tunnel) which is used for testing aeronautics and non-aeronautics fields. Power source for laboratory of BPPT unit BBTA3 Indonesia Low Speed Tunnel is supplied directly from PLN through 6 transformers owned by BBTA3. The installed load capacity for this laboratory is $3 \mathrm{MW}$, where capacity is used for testing activity and administrative activities. The first research at my office in Wind Energy System was for small load instead of for the large load. Therefore, if I see the potentials of my office, I think it is enough to develop Solar System instead of only Wind Energy system.

BPPT unit BBTA3 is located in South Tangerang area and has a high intensity of sunlight potential of $5.72 \mathrm{kWh} / \mathrm{m} 2 /$ day in $2015,4.57 \mathrm{kWh} / \mathrm{m}^{2} /$ day in 2016 and $4,63 \mathrm{kWh} / \mathrm{m}^{2} /$ day in 2017 which is enough to be an alternative renewable resources. However, it also has a flat - average wind speed in 2015, i.e. 2.14 $\mathrm{m} / \mathrm{s}, 2.43 \mathrm{~m} / \mathrm{s}$ in 2016 and $2.29 \mathrm{~m} / \mathrm{s}$ in 2017. This is the underlying application of Solar and Wind Solar Hybrids.

\section{Basic Theory}

\subsection{Solar energy}

In one day, solar cells receive solar radiation varied greatly. This is because the sun has a great intensity

\footnotetext{
* Manuscript received July 24, 2018; revised May 5, 2019.

doi: $10.12720 /$ sgce.8.4.470-477
} 
during the day compared to the morning. To know the power capacity generated, the measurement is taken to current (I) and voltage (V) to a solar cell called modules. On the curve I-V, there are very important component, namely Maximum Power Point (Vmp and Imp), Open Circuit Voltage (Voc), Short Circuit Current (Isc) and Fill Factor (FF).

\subsection{Wind energy}

Wind is the air moving from higher air pressure to lower air pressure. Differences in air pressure are caused by differences in air temperature due to unequal atmospheric warming by sunlight.

\subsubsection{Wind power generation}

The wind power plant is a power plant that uses wind as a source of energy to generate electrical energy. The following equations are used as the basis for calculating the total power generated by wind power generator, namely Wind Power, Wind Power Turbine and Generator Power.

\subsection{HOMER software}

HOMER Software is a software which is used for the operation of the generator system model in a small-scale electricity (micropower). It facilitates evaluation of power plant system design for various types of small-scale power plants whether it is connected to a power grid or not.

\subsection{Economic modelling}

\subsubsection{Total Net Present Cost (NPC)}

Total Net Present Cost (NPC) is the most important economic output for the value of a system on the wind power generator. HOMER software will sort the simulation and optimization results based on the lowest NPC value.

\subsubsection{Levelized Cost of Energy (LCOE)}

Levelized cost of energy (LCOE) is defined as the average cost per kWh of electric energy production used by the system. To calculate COE, cost annual electrical energy production is divided by total energy used electricity produced.

\section{Research Methodology}

The processes of this research are outlined in the stages as can be seen in the following flow chart:

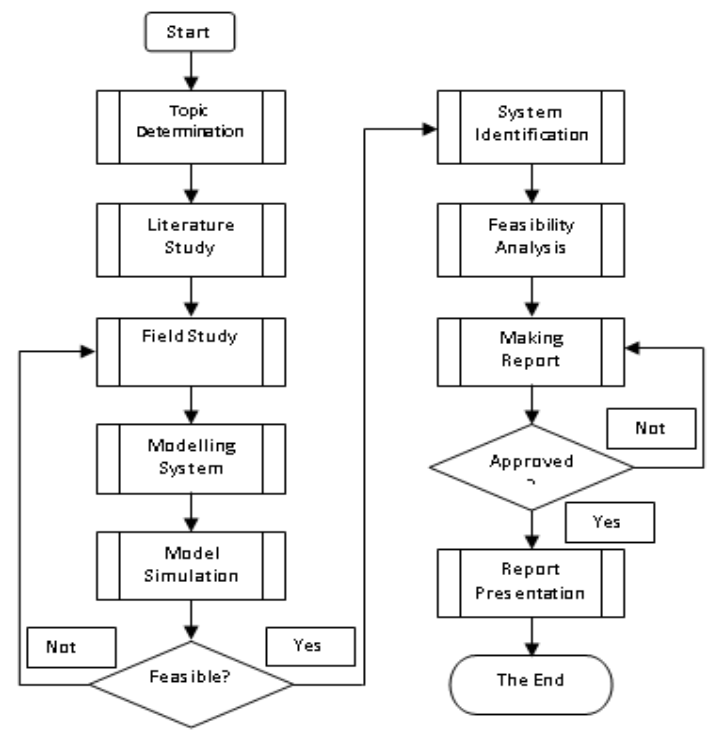

Fig. 1. Research methodology flow chart 


\subsection{Block diagram}

Figure 3 is the block diagram of the system consisting of Typical Load, PV, Wind Generator, Battery and Converter. Design for each different scheme can be analyzed to obtain the optimal sizing. In this system, there are two different busses, AC Bus $(220 \mathrm{~V})$ and DC bus $(220 \mathrm{~V})$. The minimal autonomy for the system is 4 hours to maintain the sustainability of the system at the worst case, such as black out from the source.

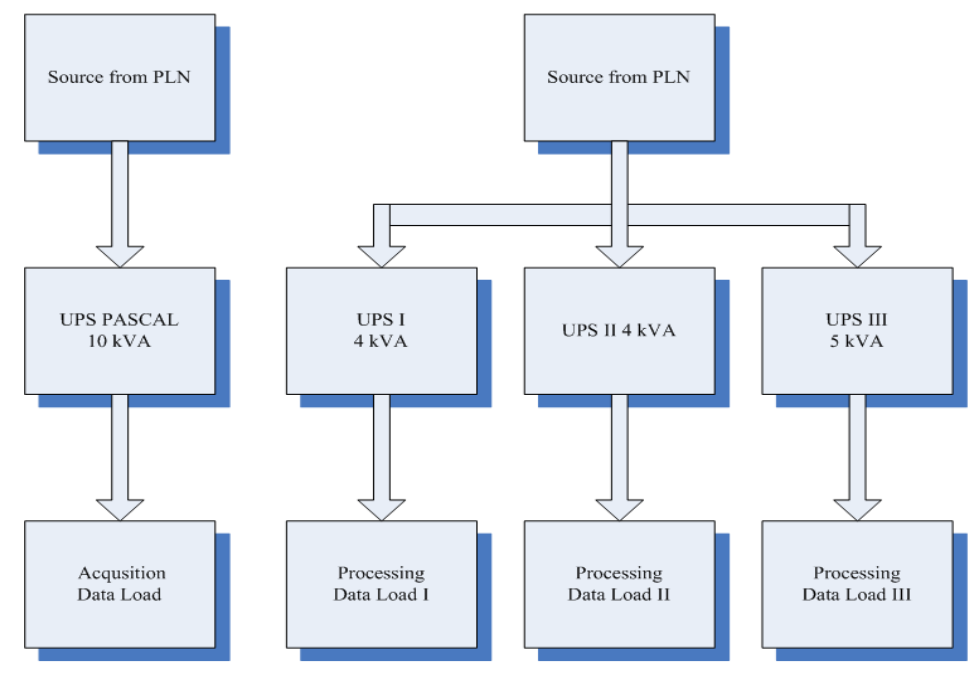

Fig. 2. Existing block diagram of the system

\subsection{Site definition}

This study is conducted at BPPT unit BBTA3. After looking thoroughly from NASA's data, there are no significant differences of the resource data. The data below was taken from BMKG in 2017 located at $6,36009^{\circ}$ South and $106,67335^{\circ}$ East.

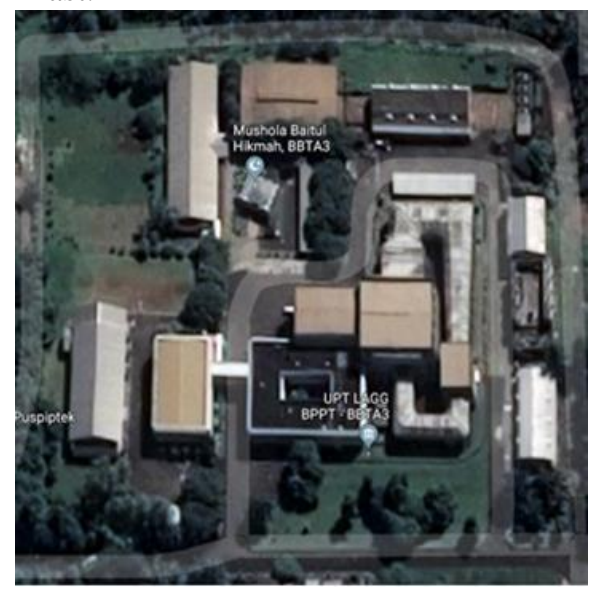

Fig. 3. BBTA3 BPPT from Top

\subsection{Load profile}

In this study, load profile uses typical load profile of processing data use and acquisition data use. The load is assumed to be constant and there's no load growth. There are 2 schemes of the load, namely:

Processing and Acquisition Data Load 


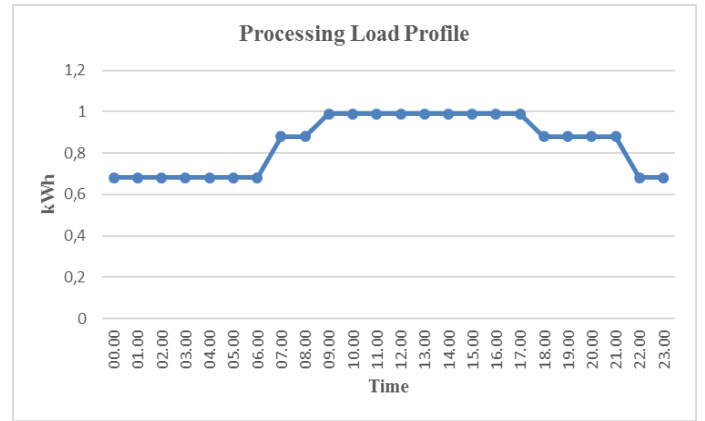

(a)

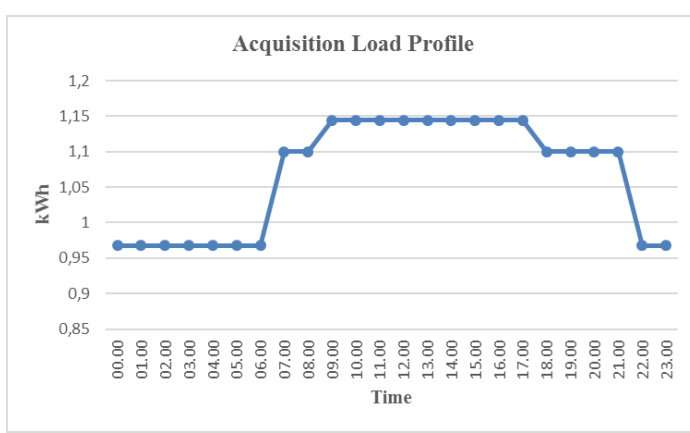

(b)

Fig. 4. Daily load profile: (a) Processing data load, (b) Acquisition data load

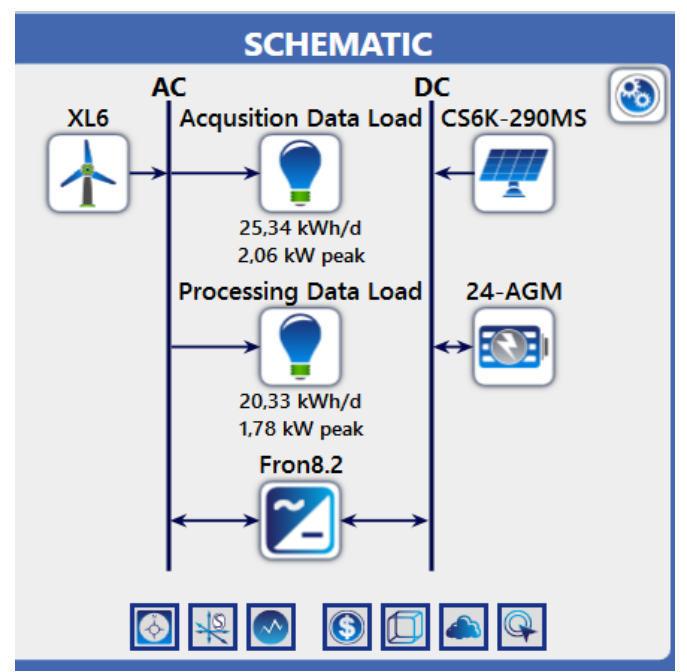

Fig. 5. Schematic design for hybrid system

\subsection{Solar energy source}

Solar Energy Source level determines the amount of electricity that can be generated by PV module. Based on BMKG (Agency of Meteorology, Climatology and Geophysics in Indonesia), in 2017, BPPT unit BBTA3 had average irradiance of $4.63 \mathrm{kWh} / \mathrm{m}^{2} /$ day and its daily level of irradiance is shown in the following figure.

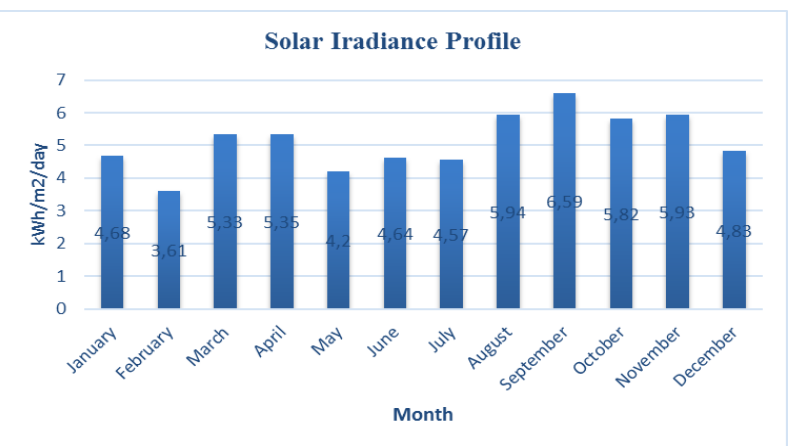

Fig. 6. Daily irradiance profile 


\subsection{Wind energy source}

Wind Energy Source level determines the amount of electricity that can be generated by wind generator. Based on BMKG (Agency of Meteorology, Climatology and Geophysics in Indonesia), in 2017, BPPT unit BBTA3 had wind power average $2.29 \mathrm{~m} / \mathrm{s}$ and its daily level of wind is shown in the following figure.

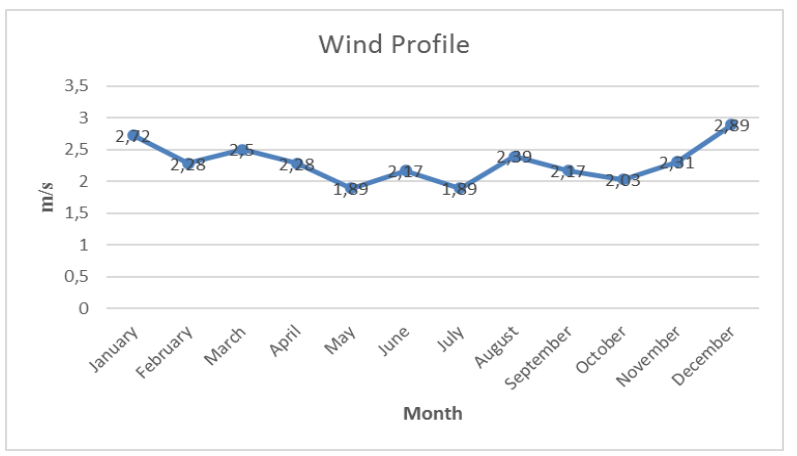

Fig. 7. Daily wind profile

\subsection{Temperature}

Based on BMKG (Agency of Meteorology, Climatology and Geophysics in Indonesia), BPPT unit BBTA3 had average temperature of $27,68{ }^{\circ} \mathrm{C}$ in 2017 and its daily level of temperature is shown in the following figure.

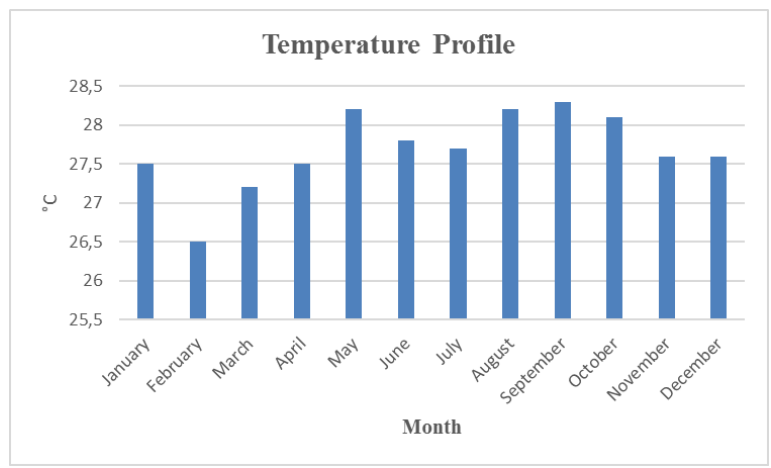

Fig. 8. Daily temperature profile

\section{Design Implementation of the System}

Firstly, we need to determine the components that will be used in fulfilling the requirement for HOMER Pro. This sizing is made by improving for acquisition and processing data load.

\subsection{PV module}

According to Minister of ESDM Indonesia, there are some minimum specifications for PV panel that can be permitted to be implemented at Indonesia, such as minimum efficiency is $14 \%$, having certificate of SNI (Indonesia National Standard), and minimum power per panel is $100 \mathrm{Wp}$. Referring to these specification, Canadian Solar $290 \mathrm{Wp}$ was chosen.

\subsection{Converter}

This study uses on-grid converter to convert the electricity between AC type and DC type. In this study, a multi-function converter was chosen. The specification of converter is Fronius 8.2-1. 


\subsection{Battery}

In this study, battery is used to store the energy from the sun and wind and to supply the load. This system was designed to withstand the worst condition (such as black out from the source) using only energy that is stored at battery for 4 hours. The DC bus voltage is set to $220 \mathrm{~V}$, therefore:

$$
E_{\text {load }}=\frac{10,4 \mathrm{kWh}}{220 \mathrm{~V}}=47,27 \mathrm{Ah}
$$

DoD based on the data sheet in normal operation is set at $80 \%$. Therefore, the required battery capacity is:

$$
E_{\text {batt }}=\frac{47,27}{0,8}=59,09 \mathrm{Ah}
$$

Because there was no 59,09 Ah battery available in the market, 67 Ah battery was selected. For a duration of 4 hours with a load of $10,4 \mathrm{~kW}$, the calculation is as follows:

$$
\begin{aligned}
\text { Backup Time } & =\frac{\text { AH } x \text { Voltage } \times N \times \text { Efficiency }}{\text { Loads }} \\
N & =\frac{41600}{562,8}=72 \text { pieces }
\end{aligned}
$$

Therefore, it needs 72 batteries for $220 \mathrm{~V}$ system or 4 battery- bank for duration of 4 hours. The specification of battery is Trojan 24-AGM.

\subsection{Wind turbine generator}

The measurement of generator power rating is based on the peak load. From the load table above, it can be determined that we need above $5 \mathrm{~kW}$ generator for acquisition \& processing data load. The generator will only turn on together with PV Module. The generator will supply the load and recharge the battery. With this system, the lifetime of the battery can be extended. The specification of Wind Turbine Generator is Bergey BWC Excel 6/50.

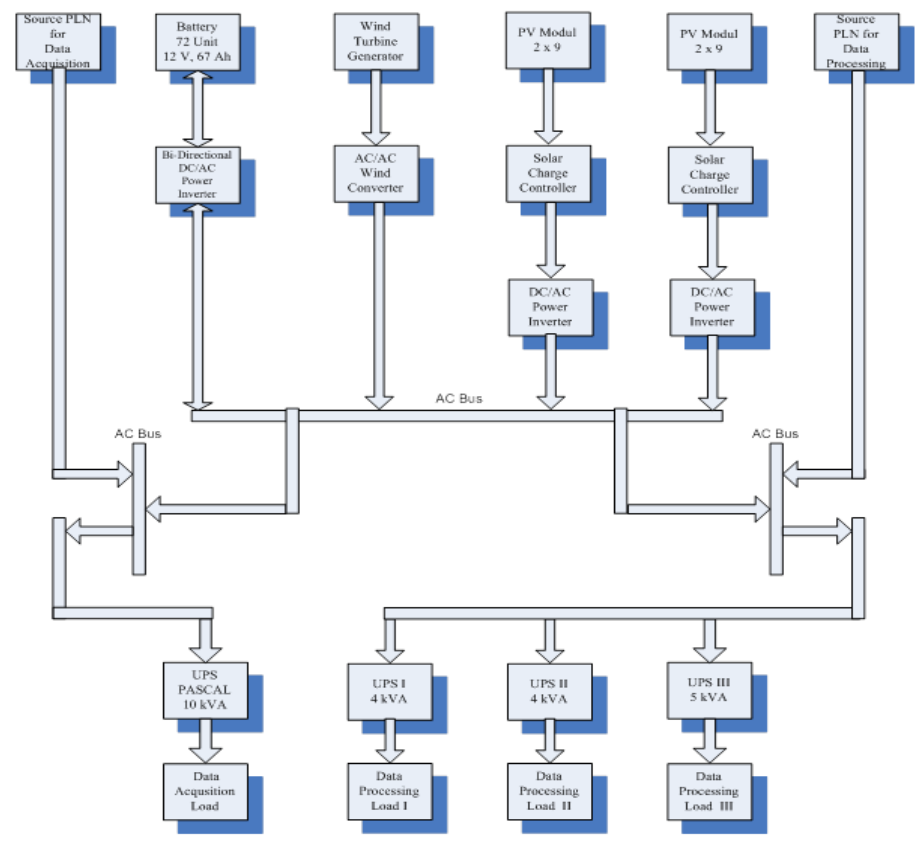

Fig. 9. New block diagram of the system 


\section{Results and Analysis}

The simulation and optimization using Homer Software produces several configurations which are different referring to the minimum contribution limits of its renewable energy.

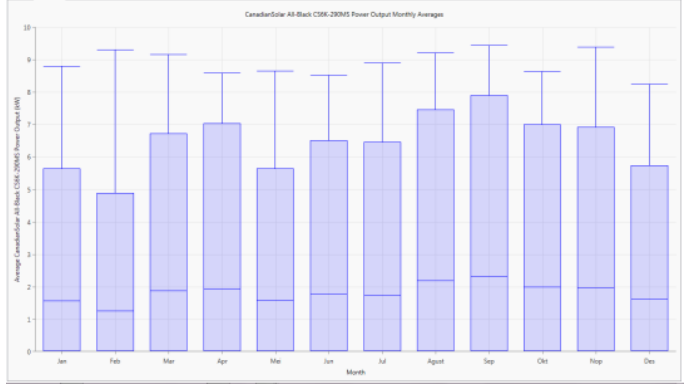

Fig. 10. PV power output

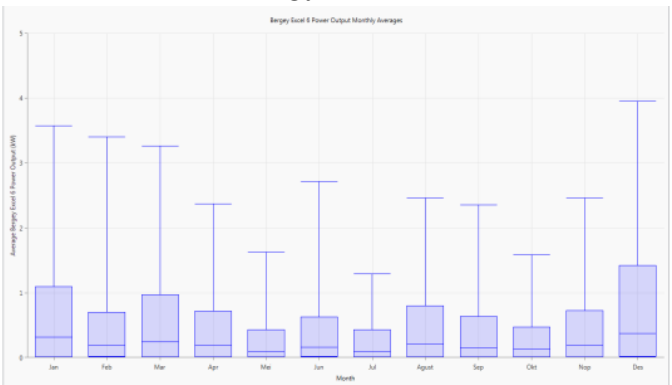

Fig. 11. Wind turbine generator power output

This part will explain the results of simulation on conditions consisting of one unit of PV and Wind Energy. The results of simulation are sorted based on the most optimal conditions and the lowest cost.

Table 5.1 Total cost of solar plants

\begin{tabular}{|l|c|c|}
\hline \multirow{2}{*}{ Parameter } & \multicolumn{2}{|c|}{ Data (USD) } \\
\cline { 2 - 3 } & BMKG 2017 & NASA 2018 \\
\hline NPC & $117,469.85$ & $114,717.78$ \\
\hline LCOE & 0.57 & 0.61 \\
\hline Operating Cost & $2,095.07$ & $1,931.99$ \\
\hline
\end{tabular}

Table 5.2 Total cost of wind power plants

\begin{tabular}{|l|c|c|}
\hline \multirow{2}{*}{ Parameter } & \multicolumn{2}{|c|}{ Data (USD) } \\
\cline { 2 - 3 } & BMKG 2017 & NASA 2018 \\
\hline NPC & $123,491.33$ & $123,491.33$ \\
\hline LCOE & 4.61 & 2.31 \\
\hline Operating Cost & $1,642.00$ & $1,642.00$ \\
\hline
\end{tabular}

Table 5.3 Total cost of solar and wind power plants

\begin{tabular}{|l|c|c|}
\hline \multirow{2}{*}{ Parameter } & \multicolumn{2}{c|}{ Data (USD) } \\
\cline { 2 - 3 } & BMKG 2017 & NASA 2018 \\
\hline NPC & $156,110.74$ & $154,114.22$ \\
\hline LCOE & 0.71 & 0.69 \\
\hline Operating Cost & $3,229.27$ & $3,093.23$ \\
\hline
\end{tabular}

\section{Conclusion}

The potential of solar irradiance at BPPT unit BBTA3 was at average of $4.63 \mathrm{kWh} / \mathrm{m}^{2} /$ day in 2017 ; hence it could generate power of $10,4 \mathrm{kWp}$ for the needs of energy generation for 4 hours. The potential of wind energy in BPPT unit BBTA3 for small-scale wind power plants development using the average wind speed in 2017 was $2.29 \mathrm{~m} / \mathrm{s}$. Therefore, it could generate electrical power of 5,5 kW. Overall, the lowest cost system is solar power plants and the most optimal systems are solar and wind power plants. To increase battery operation from 5 - 10 minutes to 4 hours, it needs 72 batteries of 12 Volt and 67 Ah.

\section{References}

[1] Suriadi and Mahdi S. Integrated Solar Power Plant (PLTS) Planning Using PVSYST Software at the Housing Complex in Banda Aceh, Electrical Engineering Journal. October 2010; 9(2),

[2] Dedy N, Syariffuddin M, Heri S. Optimization of Bayu Power Generation and Diesel Generator Using Homer Software, Department of Electrical Engineering, FTI - ITS.

[3] Muslim MM, et al. Design, Implementation and Techno-Economic Analysis of Hybrid PV-Diesel for Off-Grid System in 
Sebira Island. The $3^{\text {rd }}$ IEEE Conference on Power Engineering and Renewable Energy., Nov. 2016; 39-44.

[4] Ashish SI and Prof. Bhushan SR. Hybrid power generation system using wind energy and solar energy. International Journal of Scientific and Research Publications, March 2015; 5(3).

[5] Dede IR and Ibnu KB. Simulation of $30 \mathrm{Kwp}$ On-Grid Solar Power System at University Martim Raja Ali Haji (Umrah) Using PV*Sol Software. Department of Electrical Engineering, Faculty of Engineering, University of Maritim Raja Ali Haji, Jln. Politeknik Senggarang, Tanjungpinang 29111, Kepulauan Riau.

[6] Canadiansolar. [Online]. Available: www.canadiansolar.com

[7] Bergey. [Online]. Available: www.bergey.com

[8] FRONIUS. [Online]. Available: www.fronius.com

[9] Trojanbattery. [Online]. Available: www.trojanbattery.com

[10] Bmkg. [Online]. Available: www.bmkg.go.id

[11] [Online]. Available: www.bbta3.bppt.go.id

[12] Puspiptek. [Online]. Available: www.puspiptek.ristekdikti.go.id 